\title{
SEJARAH PEMIKIRAN EKONOMI ISLAM AL SYAIBANI DAN ABU UBAID
}

\author{
Salidin Wally \\ S2 Hukum Ekonomi Syariah UIN Sunan Gunung Djati Bandung \\ Email: salidinwally49@gmail.com
}

\begin{abstract}
ABSTRAK
Artikel ini menjelaskan tentang pemikiran ekonomi Islam menurut tokoh ekonom Islam yaitu Al Syaibani dan Abu Ubaid. Dalam pembahasannya mengemukakan tentang pemikiran dua tokoh ekonom Islam yaitu Al-Syaibani yang menitik beratkan pemikirannya terhadap ekonomi mikro dan tertuang didalam karyanya yaitu kitab al-Kasb, dan juga pemikiran Abu Ubaid yang menekankan pemikirannya kepada ekonomi makro dengan mengupas secara detail dalam kitabnya yaitu al-Amwal yang membahas tentang hak dan kewajiban negara. Dan menyimpulkan bahwa pemikiran kedua tokoh ini berbeda pandangan dalam menanggapi permasalahan ekonomi, tetapi keduanya mempunyai tujuan bersama yaitu untuk kesejahteraan ummat dan tujuan utama yaitu keridhoan Allah.

Kata Kunci: sejarah, ekonomi Islam, al-kasb, al-amwal
\end{abstract}

\section{ABSTRACT:}

This article describes about the Islamic economic thinking according to Islamic economist Al Syaibani and Abu Ubaid. In his discussion raised the thinking of two prominent Islamic economist Al Syaibani who emphasized his thoughts on microeconomics and embodied in his work namely Al-Kasb, and also Abu Ubaid's ideas which emphasize his thoughts on macroeconomics by exploring in detail in his book that is Al-Amwal discusses state rights and obligations. And concluded that the thoughts of these two figures differed in view in response to economic problems, but both have a common goal that is for the welfare of the ummah and the main goal of the keridhoan Allah.

Keywords: history, islamic economics, al-kasb, al-amwal

\section{Pendahuluan}

Mempelajari sejarah merupakan suatu keharusan bagi setiap orang yang ingin mengetahui kebenaran yang terjadi di masa lampau. Apapun jenis sejarah itu, baik berkaitan dengan politik, budaya, ekonomi dan lainnya. Banyak hal-hal yang tidak terekspos secara baik saat seseorang tidak memahami sejarah yang ada, terutama bagi seorang pembelajar yang mendalami sebuah ilmu. Berkaitan dengan ekonomi Islam, banyak hal-hal yang ada di masa Islam dahulu yang baru diketahui dan dipahami oleh segelintir orang yang memang berfokus pada bidang tersebut. Sebagai contoh setelah mempelajari Abu Yusuf dapat dipahami bahwa teori perpajakan yang banyak dicetuskan oleh bangsa barat banyak mengambil intisari dari apa yang dicetuskan oleh Abu Yusuf. Ini merupakan fakta penting terutama bagi kita yang mempelajari ekonomi 


\section{Tahkím}

Vol. XIV, No. 1, Juni 2018

Islam untuk bisa memahamkan umat tentang betapa gemilanganya ekonomi Islam di masa lalu dan urgensi kita mengetahui semua sejarah yang berkaitan dengan ekonomi Islam.

Dalam tulisan ini akan coba dipaparkan lagi tokoh sejarah ekonomi Islam di antaranya Asy Syaibani dan Abu Ubaid. Ternyata setelah ditelaah ternyata Asy Syaibani merupakan pencetus pertama sistem klasifikasi kerja. Hal ini menjadi fakta yang perlu dikaji secara lebih jauh ditambah dengan pemikiran-pemikiran lainnya dari Asy Syaibani berkaitan dengan al-Kasb, kekayaan dan kefakiran, klasifikasi usaha dan kebutuhan ekonomi dan pemikiran Abu Ubaid yang tertuang dalam kitab Al-Amwal, bahwa peranan negara dalam perekonomian yang mengulas tentang hak negara atas rakyat dan hak rakyat atas negara, dimana analisis yang digunakan beliau merujuk pada kaidah hadits-hadits yang berkaitan dengan pemerintahan. Hasil implementasi dari analisis itu direalisasikan dalam kaidah kontrak kekayaan bagi seluruh kaum muslimin yang diharapkan mampu menambah khazanah intelektual kita berkaitan dengan sejarah ekonomi Islam.

\section{Biografi Al Syaibani}

Abu Abdillah Muhammad bin Al-Hasan bin Farqad al-Syaibani lahir pada tahun $132 \mathrm{H}(750 \mathrm{M})$ di kota Wasith, ibukota Irak pada masa akhir pemerintahan Bani Umayyah. Ayahnya berasal dari negeri Syaiban di wilayah Jazirah Arab. bersama orang tuanya, Al Syaibani pindah ke kota Kufah yang ketika itu merupakan salah satu pusat kegiatan ilmiah. Di kota tersebut ia belajar fiqh, sastra, bahasa, dan hadis kepada para ulama setempat, seperti Mus'ar bin Kadam, Sufyan Tsauri, Umar bin Dzar, dan Malik bin Maghul. Pada saat berusia 14 tahun berguru kepada Abu Hanifah selama 4 tahun, yakni sampai Abu Hanifa meninggal dunia. Setelah itu, ia berguru pada Abu Yusuf, salah seorang murid terkemuka dan pengganti Abu Hanifah, hingga keduanya tercatat sebagai penyebar mazhab Hanafi. ${ }^{1}$

Dalam menuntut ilmu, al-Syaibani banyak berinteraksi dengan berbagai ulama. Layaknya ulama terdahulu, ia berkelana ke berbagai tempat, seperti Madinah, Makkah, Syiria, Basrah dan Khurasan untuk belajar pada ulama besar, seperti Malik bin Anas, Sufyan bin 'Uyainah, dan Auza'i. Ia juga pernah bertemu dengan Al Syafi'i ketika belajar Al Muwattha pada Malik bin Anas. ${ }^{2}$ Hal tersebut memberikan nuansa baru dalam pemikiran fiqihnya. Al-Syaibani menjadi lebih banyak mengetahui berbagai hadis yang luput dari pengetahuan Abu Hanifah. Dari keluasan Pendidikannya ini, ia

\footnotetext{
${ }^{1}$ Adiwarman A. Karim, Sejarah Pemikiran Ekonomi Islam, (Ed. 3; Jakarta: PT. Raja Grafindo Persada, 2004), h. 254

${ }^{2}$ Dalam perkembangan selanjutnya imam Syafi'i belajar fiqih kepada Al-Syaibani selama kurang lebih 2 tahun. Lihat Rifa'at Al-Audi, Min al-Turats: al-Iqtishad li al-Muslimin (Cet. 4; Makkah: Rabithah 'Alam al Islami, 1985), h. 20.
} 


\section{Tahkím}

Vol. XIV, No. 1, Juni 2018

mampu mengombinasikan antara aliran ahl al-ra'yi di Irak dan ahl al-hadits di Madinah. $^{3}$

Setelah memperoleh ilmu yang memadai, al-Syaibani kembali ke Baghdad yang pada saat itu telah berada dalam kekuasaan Bani Abbasiyah. Di tempat ini, ia mempunyai peranan penting dalam majelis ulama dan kerap didatangi para penuntut ilmu. Hal tersebut makin mempermudahnya dalam mengembangkan mazhab Hanafi, apalagi ditunjang kebijakan pemerintah saat itu yang menjadikan mazhab hanafi sebagai mazhab negara. Berkat keluasan ilmunya tersebut, setelah Abu Yusuf meninggal dunia, Khalifah Harun Al Rasyid mengangkatnya sebagai hakim di kota Riqqah, Iraq. Namun, tugas ini hanya berlangsung singkat karena ia kemudian mengundurkan diri untuk lebih berkonsentrasi pada pengajaran dan penulisan fiqih. AlSyaibani meninggal dunia pada tahun 189 H (804 M) di kota al-Ray, dekat Teheran, dalam usia 58 tahun. $^{4}$

Selama hidupnya beliau dikenal sebagai ekonom muslim yang produktif. Dalam menuliskan pokok-pokok pemikiran fiqihnya, al-Syaibani menggunakan istihsan sebagai metode ijtihadnya. Hasil karyanya yang berupa kita diklasifikasikan menjadi dua golongan, yaitu:

1. Zharir al Riwayah, yaitu kitab yang dituliskan berdasarkan pelajaran yang diberikan Abu Hanifah, seperti al Mabsut, al Jami' al Kabir, al Jami' al Saghir, al Siyar al Kabir, al Siyar al Saghir, dan al Ziyadat. Semua ini dihimpun Abi Al Fadl Muhammad ibn Muhammad ibn Ahmad Al Maruzi dalam satu kitab berjudul Al Kafi.

2. Al Nawadir, yaitu kitab yang ditulis berdasarkan pandangannya sendiri, seperti Amali Muhammad fi al Fiqh, al Ruqayyat, al Makharij fi al Hiyal, al Radd 'ala Ahl Madinah, al Ziyadah, al Atsar, dan al Kasb. ${ }^{5}$

\section{Biografi Abu Ubaid}

Abu Ubaid bernama Lengkap Al-Qasim bin Sallam bin Miskin bin Zaid AlHarawi Al-Azadi Al-Baghdadi. Beliau terlahir dikota Hirrah Khurasan sebelah barat laut Afganistan pada tahun $150 \mathrm{H}$ dari ayah keturunan Byzantium, maula dari suku Azad. Abu Ubaid hidup pada masa Daulah Abasiyah mulai dari khalifah Al mahdi, Beliau merupakan seorang ulama yang cerdas dan pintar sehingga banyak ulama yang memujinya.

Pada tahun 192 H, Tsabit ibn Nashir ibn Malik, Gubernur Thugur di masa pemerintahan Khalifah Harun Ar Rasyid, mengangkat Abu Ubaid sebagai qadh'i (hakim) di Tarsus hingga tahun $210 \mathrm{H}$. Setelah itu, penulis al-Amwal ini tinggal di

\footnotetext{
${ }^{3}$ Abdul Aziz Dahlan dkk (ed.), Ensiklopedi Hukum Islam, Jilid 5, (Cet. 1; Jakarta : PT. Ichtiar Baru Van Hoeve, 1997), h.1686.

${ }^{4}$ Adiwarman A. Karim, op.cit., h. 255

${ }^{5}$ Abdul Aziz Dahlan, dkk (ed.), op.cit., h. 1687
} 


\section{Tahkím}

Vol. XIV, No. 1, Juni 2018

Baghdad selama 10 tahun. Pada tahun $219 \mathrm{H}$, setelah berhaji ia tinggal di Mekkah sampai wafat, ia meninggal pada tahun $224 \mathrm{H}^{6}{ }^{6}$

Menurut Ibnu Rohubah "kita memerlukan seseorang seperti Abu Ubaid tetapi Abu Ubaid tidak memerlukan kita." Sedangkan menurut Ahmad bin Hambal, Abu Ubaid adalah orang yang bertambah kebaikannya setiap harinya. Abu ubaid menyusun suatu ikhtisar tentang keuangan publik yang bisa dibandingkan dengan kitab Al-kharaj Abu Yusuf. Karyanya kitab Al-amwal sangat kaya dengan sejarah materi ilmu hukum. Para penulis ekonomi Islam banyak mengutip buku ini. Bahkan telah diterjemahkan kedalam bahasa Urdu tanpa ada pengantar ataupun analisis terhadap isinya. ${ }^{7}$

Bagi Abu Ubaid satu hari mengarang itu lebih utama baginya dari pada memukulkan pedang di jalan Allah. Kitab Al-Amwal dari Abu Ubaid merupakan suatu karya yang lengkap tentang tentang keuangan negara Islam. Kitab al amwal ini sangat kaya dengan sejarah perekonomian dari separuh pertama abad kedua Islam. buku ini juga merupakan ringkasan tradisi asli dari Nabi saw dan laporan para sahabat dan pengikutnya tentang masalah ekonomi.

\section{Pemikiran Ekonomi Asy Syaibani}

Asy Syaibani merupakan salah seorang tokoh ekonomi islam yang punya dampak yang cukup besar terhadap perkembangan ekonomi Islam. Bahkan Al- Janidal menyatakan bahwa Al-Syaibani merupakan salah seorang perintis ilmu ekonomi dalam Islam. ${ }^{8}$ Sebagai buktinya dapat kita lihat dari pemikiran-pemikiran ekonomi yang beliau cetuskan yakni:

\section{Al-Kasb (Kerja)}

Al Syaibani mendefinisikan al kasb (kerja) sebagai cara memcari perolehan harta melalui berbagai cara yang halal. ${ }^{9}$ Dalam ilmu ekonomi, aktivitas tersebut dikenal sebagai aktivitas produksi. Dari definisi yang ada pada awal paragraf terlihat bahwa ada perbedaan yang sangat mendasar antara ekonomi Islam dan ekonomi konvensional. Dimana pada konvensional segala aspek produksi baik itu yang halal maupun yang haram dibolehkan, sedangkan dalam ekonomi islam aspek produksi hanya berkutat pada yang halal saja. Ini merupakan perbedaan yang sangat fundamental sekali karena ekonomi islam sangat menjunjung aspek kehalalan dari semua segi baik itu sumber, cara maupun hasilnya.

Produksi suatu barang dalam ilmu ekonomi dilakukan karena ia mempunyai utilitas (nilai guna). Dalam ekonomi islam nilai guna tersebut diukur dari

${ }^{6}$ Adiwarman Azwar Karim, Sejarah Pemikiran Ekonomi Islam, (Jakarta: PT Raja Grafindo Persada, 2012), h. 264

${ }^{7}$ Adiwarman Azwar Karim, Sejarah Pemikiran Ekonomi Islam, (Jakarta: The International Institute Of Islamic Tought Indonesia,2002), h. 13

${ }^{8}$ Hammad bin Abdurrahman Al Janidal, Manahij al-Bahitsin fi al Islami, Jilid 2,(Riyadh : Syirkah al Ubaikan li al Thaba'ah wa al Nasyr, 1046 H), h. 111

${ }^{9}$ Rifa'at al Daudi, op cit., h. 25 


\section{Tahkím}

Vol. XIV, No. 1, Juni 2018

kemaslahatannya. ${ }^{10}$ Seperti yang diungkapkan oleh Al-Syatibi, bahwa kemaslahatan hanya bisa dicapai dengan memlihara lima unsur pokok kehidupan, yaitu agama, jiwa, akal, keturunan, dan harta. ${ }^{11}$ Hal inilah yang mendasari perbedaan produsen antara ekonomi Islam dan konvensional. Dimana dalam ekonomi islam tujuan produsen tersebut adalah maqasid syari'ah yaitu memelihara kemaslahatan manusia baik dunia maupun akhirat. Berbeda dengan konvensional yang beorientasi pada tujuan dunia semata dimana setiap produksi bisa dilakukan jika ada orang yang yang menginginkan hasil produksi tesebut tanpa melihat efek maslahatnya secara keseluruhan. ${ }^{12}$

Dalam pandangan Islam aktivitas merupakan kewajiban 'imaratul kaun, yakni menciptakan kemakmuran semesta untuk semua mahluk. Berkenaan dengan hal tersebut, Al Syaibani menegaskan bahwa bahwa kerja merupakan unsur penting dalam kehidupan karena menunjang pelaksanaan ibadah dan karena hal tersebut maka hukum bekerja adalah wajib. ${ }^{13}$ Hal ini didasari pada dalil sebagai berikut $:{ }^{14}$

a. Firman Allah.

Apabila telah ditunaikan shalat, maka bertebaranlah kamu di muka bumi dan carilah karunia Allah dan ingatlah Allah banyak-banyak supaya kamu beruntung. (QS. Al-Jumu'ah: 10)

b. Hadis Rasulullah Saw: "Mencari pendapatan adalah wajib bagi setiap Muslim."

c. Ijtihad Amirul Mukminin Umar ibn Khattab yang mengutamakan derajat kerja daripada jihad. Sayyidina Umar menyatakan, dirinya lebih menyukai meninggal pada saat berusaha mencari sebagian karunia Allah Swt. dimuka bumi daripada terbunuh di medan perang, karena Allah Swt. mendahulukan orang-orang yang mencari sebagian karunia-Nya daripada mujahidin melalui firman-Nya : ....Dan orang-orang yang berjalan di muka bumi mencari sebagian karunia Allah dan orang-orang yang lain lagi yang berperang di jalan Allah.. (Al Muzammil: 20)

Berkenaan dengan hal tersebut, Al-Syaibani menyatakan bahwa sesuatu yang dapat menunjang terlaksananya yang wajib maka hukumnya menjadi wajib hukumnya. Lebih jauh, ia menguraikan bahwa untuk menunaikan berbagai kewajiban, seseorang memerlukan kekuatan jasmani dan kekuatan jasmani itu sendiri merupakan hasil dari konsumsi makanan yang diperoleh dari kerja keras. Dengan demikian, kerja

\footnotetext{
${ }^{10}$ Lihat Abulhasan M. Sadeq dan Aidit Ghazali, Reading in Islamic Economic Thought (Cet. 1; Selangor Darul Ehsan Longman Malaysia, 1992), h. 194-196

${ }^{11}$ Asafri Jaya Bakri, Konsep Maqashid Syari'ah Menurut Al Syatibi, (Cet. 1; Jakarta: PT. Raja Grafindo Persada, 1996), h. 71

${ }^{12}$ Taqiyuddin Al-Nabhani, Membangun Sistem Ekonomi Alternatif: Perspektif Islam (Cet. 2; Surabaya: Risalah Gusti, 1996), h. 1-46

${ }^{13}$ Muhammad bin Hasan Al Hasan Al Syaibani, al Iktisab fi al Rizq al Mustahab (Cet. 2; Beirut: Dar al Kutub al Ilmiyyah, 1986), h. 17

${ }^{14}$ Rifa'at Al Audi, op. Cit., h. 25-26
} 


\section{Tahkím}

Vol. XIV, No. 1, Juni 2018

mempunyai peranan yang sangat penting dalam menunaikan suatu kewajiban dan karena hal tersebut maka hukum bekerja adalah wajib seperti kewajiban thaharah ketika akan melaksanakan shalat. ${ }^{15}$ Di samping itu, Al Syaibani juga menyatakan bahwa bekerja merupakan ajaran para rasul terdahulu dan kaum muslimin diperintahkan untuk meneladani mereka.

Dari uraian tersebut, jelas bahwa orientasi bekerja dalam pandangan $\mathrm{Al}$ Syaibani adalah hidup untuk mencari ridho Allah Swt. Di sisi lain, kerja merupakan usaha untuk mengaktifkan roda perekonomian, termasuk proses produksi, konsumsi dan distribusi, yang berimplikasi secara makro meningkatkan pertumbuhan ekonomi suatu negara. Dengan demikian, kerja mempunyai peranan yang sangat penting dalam memenuhi hak Allah Swt., hak hidup, hak keluarga, dan hak masyarakat.

\section{Kekayaan dan Kefakiran}

Menurut Al-Syaibani, sekalipun banyak dalil yang menunjukkan keutamaan sifat-sifat kaya, sifat-sifat fakir mempunyai kedudukan yang lebih tinggi. Ia menyatakan bahwa bahwa apabila manusia telah merasa cukup dari apa yang dibutuhkan kemudian bergegas pada kebajikan, sehingga mencurahkan perhatian pada urusan akhiratnya, adalah lebih baik bagi mereka. ${ }^{16}$

Dalam konteks ini, sifat-sifat fakir diartikannya sebagai kondisi cukup (kifayah), bukan kondisi papa dan meminta-minta (kafafah) ${ }^{17}$ Dengan demikian, pada dasarnya Al Syaibani menyerukan agar manusia hidup dalam kecukupan, baik untuk dirinya sendiri maupun keluarganya. Di sisi lain, ia berpendapat bahwa sifat-sifat kaya berpotensi membawa pemiliknya pada kemewahan. ${ }^{18}$ Sekalipun begitu, ia tidak menentang gaya hidup yang lebih dari cukup asalkan kelebihan tersebut digunakan untuk kebaikan. ${ }^{19}$

\section{Klasifikasi Usaha-Usaha Perekonomian}

Menurut Al-Syaibani, usaha-usaha perekonomian terbagi atas empat macam, yaitu sewa menyewa, perdagangan, pertanian, dan perindustrian. ${ }^{20}$ Sedangkan para ekonom kontemporer membagi menjadi tiga bagian, yaitu pertanian, perindustrian, dan jasa. Jika ditelaah lebih dalam maka usaha juga meliputi kedalam perdagangan. Di antara keempat usaha perekonomian tersebut, Al Syaibani lebih mengutamakan usaha pertanian dibandingkan dengan usaha lainnya. Menurutnya, usaha pertanian memproduksi berbagai kebutuhan dasar manusia dalam rangka pemenuhan berbagai kewajibannya. $^{21}$

\footnotetext{
${ }^{15}$ Muhammad bin al Hasan Al Syaibani, op.cit., h. 19

${ }^{16}$ Ibid., h. 30

${ }^{17}$ Rifa'at Al-Audi, op.cit., h. 31.

${ }^{18}$ Muhammad bin al Hasan Al Syaibani, op.cit., h. 32

${ }^{19}$ Rifa' at Al-Audi, op.cit., h. 41

${ }^{20}$ Muhammad bin al Hasan Al Syaibani, op.cit., h. 40

${ }^{21}$ Ibid., h. 41.
} 


\section{Tahkim}

Vol. XIV, No. 1, Juni 2018

Dari segi hukum, Al-Syaibani membagi usaha perekonomian menjadi dua, yaitu fardu kifayah dan fardu 'ain. Berbagai usaha perekonomian dihukumi fardu kifayah apabila telah ada orang-orang yang menjalankan aktivitas perekonomian sebagai dampaknya maka berjalanlah roda perekonomian atau berkaitan dengan usaha bersama. Hanya apabila terdapat individu yang tidak menjalankan fungsinya dalam usaha tersebut maka bisa berdampak buruk pada berlangsungnya aktivitas usaha tersebut sehingga memberikan dampak buruk pada individu-individu yang ada didalamnya. ${ }^{22}$

Sedangkan suatu usaha dikukum fardu 'ain berkaitan dengan kebutuhan individu. Disini setiap orang wajib memenuhi kebutuhan hidupnya, apakah itu untuknya, istrinya maupun keluarganya. Hal ini tidak bisa terlaksana, jika individu tidak menjalankan usahanya sendiri yang nantinya berakibat pada kebinasaan diri dan keluarganya.

\section{Kebutuhan-Kebutuhan Ekonomi}

Al Syaibani mengatakan bahwa sesungguhnya Allah menciptakan anak-anak Adam sebagai suatu ciptaan yang tubuhnya tidak akan berdiri kecuali dalam empat perkara, yaitu makan, minum, pakaian, dan tempat tinggal. ${ }^{23}$ Para ekonom yang lain mengatakan bahwa keempat hal ini adalah tema ilmu ekonomi. Jika keempat hal tersebut tidak pernah diusahakan untuk dipenuhi, manusia akan mengalami kesengsaraan karena manusia tak akan dapat hidup tanpa keempat hal tersebut. ${ }^{24}$

\section{Spesialisasi dan Distribusi Pekerjaan}

Syaibani menyatakan bahwa manusia dalam hidupnya selalu membutuhkan yang lain. Seseorang tidak akan menguasai pengetahuan semua hal yang dibutuhkan sepanjang hidupnya dan kalaupun manusia berusaha keras, usia akan membatasi dirinya. Dalam hal ini, kemaslahatan hidup manusia sangat tergantung pada dirinya. Oleh karena itu, Allah memberi kemudahan pada setiap orang untuk menguasai pengetahuan mengenai salah satu diantara kebutuhan tersebut, sehingga manusia sapat bekerja sama dalam memenuhi kebutuhan hidupnya. ${ }^{25}$ Firman Allah:

..Dan Kami telah meninggikan sebagian mereka atas sebagian yang lain beberapa derajat... (Surat Az Zukhruf : 32)

Lebih lanjut Al-Syaibani menandaskan bahwa seorang yang fakir membutuhkan orang kaya sedangkan yang kaya membutuhkan tenaga yang miskin. Dari hasil tolongmenolong tersebut, manusia akan semakin mudah dalam menjalankan aktibitas ibadah kepada-Nya. ${ }^{26}$ Dalam konteks ini Allah berfirman:

\footnotetext{
${ }^{22}$ Ibid., h. 45.

${ }^{23}$ Ibid., h. 47.

${ }^{24}$ Ibid., h. 48.

${ }^{25}$ Ibid., h. 47.

${ }^{26}$ Ibid., h. 48
} 


\section{Tahkím}

Vol. XIV, No. 1, Juni 2018

..Dan saling menolonglah kamu sekalian dalam kebaikan dan ketakwaan.. (Al Maidah : 2)

Rasulullah juga bersabda, "Sesungguhnya Allah swt. selalu menolong hamba-Nya selama hamba-Nya tersebut menolong saudara Muslimnya. (HR. Bukhari-Muslim)

Lebih jauh, Al Syaibani mengatakan, bahwa apabila seseorang bekerja dengan niat melaksanakan ketaatan kepada-Nya atau membantu saudaranya untuk melaksanakan ibadah kepadaNya, pekerjaan tersebut dibalas sesuai dengan niatnya. ${ }^{27}$ Dengan demikian distribus pekerjaan seperti pekerjaan diatas merupakan objek ekonomi yang mempunyai dua aspek sekaligus, yakni aspek religius dan aspek ekonomis.

\section{Pandangan Abu Ubaid Tentang Ekonomi Islam}

\section{Filosofi Hukum dari Sisi Hukum ${ }^{28}$}

Jika isi buku al-Amwal Abu Ubaid dievaluasi dari sisi filsafat hukum maka akan tampak, bahwa Abu Ubaid menekankan keadilan sebagai prinsip utama. Baginya, tujuan dari prinsip ini akan membawa kepada kesejahteraan ekonomi dan keselarasan sosial. Pada dasarnya ia memiliki pendekatan yang berimbang kepada hak-hak individual, publik dan negara, jika kepentingan individual berbenturan dengan kepentingan publik maka ia akan berpihak pada kepentingan publik.

Tulisan-tulisan Abu Ubaid lahir pada masa Abasiyah sehingga banyak pemikirannya menekankan pada kebijakan pemerintah untuk membuat suatu keputusan. Khalifah diberikan kebebasan dalam memilih diantara pandangan Abu Ubaid, yang terpenting berdasarkan Al-Qur'an dan Hadis serta untuk kepentingan umum. Contoh, Abu Ubaid berpendapat bahwa zakat dari tabungan dapat diberikan pada negara ataupun penerimanya sendiri. Sedangkan zakat komoditas harus diberikan kepada pemerintah, jika tidak maka kewajiban agama diasumsikan tidak ditunaikan. Abu Ubaid juga mengakui otoritas pemerintah dalam memutuskan, apakah akan membagikan kepada penakluk ataupun membiarkan kepemilikannya kepada penduduk setempat. Abu Ubaid juga menegaskan bahwa kas negara tidak boleh disalahgunakan untuk kepentingan pemimpin.

Berkaitan dengan pajak tanah dan poll-tax, ia menyinggung tentang pentingnya keseimbangan antara kekuatan finansial penduduk non-muslim yang dalam bahasa modern disebut capacity to pay dan juga memperhatikan kepentingan para penerimanya yaitu golongan muslim. Dengan demikian Abu Ubaid berusaha menghentikan diskriminasi (penindasan) dalam perpajakan.

\footnotetext{
${ }^{27}$ Loc. cit.

${ }^{28}$ Adiwarman Azwar Karim, Sejarah Pemikiran Ekonomi Islam, h. 272-273
} 


\section{Tahkim}

Vol. XIV, No. 1, Juni 2018

\section{Dikotomi Badui - Urban ${ }^{29}$}

Pembahasan mengenai dikotomi dilakukan Abu Ubaid ketika menyoroti alokasi pendapatan fai'. Berbeda dengan kaum Badui, kaum Urban (perkotaan) :

1. ikut serta dalam keberlangsungan negara dengan berbagai kewajiban administrasi dari semua muslim.

2. Memelihara dan memperkuat pertahanan sipil melalui mibilisasi jiwa dan harta mereka.

3. Menggalakkan pendidikan dan pengajaran melalui pembelajaran dan pengajaran Al-Qur'an dan Al-Sunnah, serta penyebaran keunggulannya (keunggulan kualitas isinya).

4. Melakukan kontribusi terhadap keselarasan sosial melalui pembelajaran dan penerapan Hudud.

5. Memberikan contoh universalisme islam dengan sholat berjamaah pada waktu jum'at.

Dari keterangan di atas dapat diketahui bahwa Abu Ubaid mengembangkan suatu negara dengan sistem administrasi yang baik. Diantara administrasi tersebut ialah:

a) Pertahanan

b) Pendidikan

c) Hukum

Semua kaum mendapatkan alokasi dari fai' tersebut, sedangkan kaum badui biasanya tidak ikut serta melaksanakan kewajiban publik seperti sebagaimana kewajiban kaum urban.

Sehingga kaum badui tidak menerima manfaat pendapatan fai' seperti kaum Urban. Kaum Badui hanya dapat mengklaim sementara terhadap pendapatan fai' yang hanya saat terjadi kondisi krisis seperti saat terjadi invasi atau penyerangan musuh, kekeringan yang dahsyat, dan kerusuhan sipil.

\section{Kepemilikan dalam konteks kebijakan Perbaikan Pertanian}

Abu Ubaid mengakui adanya kepemilikan pribadi dan kepemilikan publik. Sesuatu yang baru dalam hubungan antara kepemilikan dengan kebijakan perbaikan pertanian ditemukan oleh Abu Ubaid: yaitu berupa kebijakan pemerintah, seperti Iqta' tanah gurun dan deklarasi resmi terhadap kepemilikan individu atas tanah tandus yang disuburkan. Maka tanah tersebut diberikan dengan persyaratan diolah dan dibebaskan dari membayar pajak, tetapi jika tanah tersebut di biarkan menganggur selama 3 tahun berturut-turut, maka akan di denda dan dialihkan kepemilikan atas nama tanah tersebut. Tanah gurun yang termasuk dalam hima juga akan di reklamasikan jika tidak ditanami selama 3 tahun dapat ditempati orang lain. Menurut Abu Ubaid sumber dari publik seperti Air, Padang rumput Pengembalaan, dan Tambang minyak tidak boleh di

${ }^{29}$ Ibid., 275 


\section{Tahkím}

Vol. XIV, No. 1, Juni 2018

monopoli seperti pada Hima. Semua sumber daya tersebut dikelola untuk negara dan mensejahterakan masyarakat. ${ }^{30}$

\section{Pertimbangan kebutuhan}

Pertimbangan kebutuhan yang di maksud adalah Abu Ubaid sangat tidak setuju ketika pembagian zakat dibagikan merata kepada 8 kelompok penerima zakat. Karena masing-masing di antara 8 penerima zakat mempunyai kebutuhan yang berbeda, sehingga zakat tidak harus sama bagiannya.

Abu Ubaid tidak memberikan hak zakat kepada orang-orang yang memiliki 40 dirham atau harta lainnya yang setara, dan di sisi lain orang yang memiliki 200 dirham wajib mengeluarkan zakat. Dari keterangan di atas, Abu Ubaid meng identifikasikan ada tiga kelompok sosio-ekonomi yang berkaitan dengan status zakat yaitu:

$>$ Kalangan orang kaya yang terkena wajib zakat.

Kalangan menengah yang tidak terkena wajib zakat, tetapi juga tidak berhak menerima zakat.

Kalangan penerima zakat.

Cara mendistribusikan zakat kepada kalangan penerima zakat, Abu Ubaid mengumpulkan zakat tersebut kepada petugas pengumpul zakat (amil) dan memberikan zakat sesuai hak-nya. ${ }^{31}$

\section{Peran negara dalam perekonomian}

Pemikiran Abu Ubaid yang tertuang dalam kitab al amwal adalah peranan negara dalam perekonomian yang mengulas tentang hak negara atas rakyat dan hak rakyat atas negara, dimana analisis yang digunakan beliau merujuk pada kaidah haditshadits yang berkaitan dengan pemerintahan. Hasil implementasi dari analisis itu direalisasikan dalam kaidah kontrak kekayaan bagi seluruh kaum muslimin. Unsurunsur kontrak itu meliputi:

1. Azas pengelolahan harta didasarkan atas ketaqwaan kepada Allah swt

2. Keberadaan kekayaan pada komunitas kaum muslimin merupakan tanggung jawab seluruhnya, dan kepala negara berhak menggunakannya demi kepentingan seluruh kaum muslimin.

3. Setiap perbuatan dihadapkan pada tanggungjawab, pemerintah harus menjaga keamanan, meningkatkan kesejahteraan, melindungi hak-hak rakyat, mengatur kekayaan publik, dan menjamin terpeliharanya maqasid syariah.

Abu Ubaid menjadikan keadilan sebagai prinsip dasar (basic princivil) dalam misi kekhalifahan. Diriwayatkan dari Imam Ali ra "keadilan adalah suatu hak dan pemerintah wajib menegakan hukum sesuai dengan Allah syariatkan dan menjalankan

\footnotetext{
${ }^{30}$ Ibid., h. 277

${ }^{31}$ Ibid., h. 278-279
} 


\section{Tahkím}

Vol. XIV, No. 1, Juni 2018

amanat, ketika pemerintah melakukan hal tersebut wajib bagi rakyat mendengar, menaati, memenuhi panggilan negara dan pemerintah."

Khalifah dan pemerintah menempatkan hukum dan berdasarkan Al-Qur'an dan menyayangi rakyatnya sebagaimana lelaki menyayangi keluarganya. Peran negara begitu besar dalam perekonomian karena tugas negara adalah menegakan kehidupan sosial berdasarkan nila-nilai keadilan yang disyariatkan , seperti penerapan zakat dapat mengikis kesenjangan sosial dan menumbuhkan kepedulian sosial. Dan dengan mengatur administrasi keuangan negara seefektif mungkin sehingga penyediaan kebutuhan pokok, fasilitas umum, distribusi pendapatan dapat menjamin kemaslahatan umat sehingga terselenggara kegiatan ekonomi yang berkeadilan. Dimana sasaran beliau adalah legitimasi dari sosio-politik ekonomi yang stabil dan adil. ${ }^{32}$

\section{Sumber Penerimaan Keuangan Publik}

Kitab Al-Amwal Abu Ubaid secara khusus memusatkan perhatian sekitar keuangan publik (public finance), analisis yang beliau titik beratkan adalah pada praktek yang dilakukan Rasulullah, Khulafaurrasyidin, terutama Umar bin Khattab dan Umar bin Abdul Azis sebagai contoh ideal dalam pengelolaan keuangan publik. Institusi yang mengelola disebut Baitul Mal.

Baitul Mal terbentuk setelah perang Badar menurut pendapat yang diunggulkan (qaul Rajih), karena waktu kaum muslim mendapatkan harta rampasan perang (ghanimah) yang banyak, dan pada waktu tempat penyimpanan kekayaan negara seperti ghanimah, shadaqoh, dan fa'i adalah masjid. Kedua, adalah harta shafi yang Rasulullah saw dipilih dari ghanimah yang diperoleh kaum muslimin sebelum harta itu dibagikan. Sebagaimana riwayat Ibnu Abbas dari Rasulullah saw "Berikanlah dari harta ghanimah bagian Rasulullah dan shafi." Ketiga, adalah harta 1/5 dari ghanimah yang telah dibagi.

Namun perlu diketahui bahwa sebagaimana menurut takwil Umar bin Khattab ada tiga harta yang masuk dalam keuangan publik yaitu; shodaqoh, fa'i, dan khumus. Tetapi menurut Abu Ubaid harta yang masuk dalam keuangan publik, yaitu sebagai berikut: ${ }^{33}$

1) Shodaqoh/Zakat

Dalam hal ini, shodaqoh wajib atau yang disebut zakat harta seperti zakat emas, perniagaan, unta, sapi, kambing, biji-bijian dan buah-buahan. Dimana dari zakat harta ini dialokasikan untuk delapan golongan yang Allah sebutkan dalam Al-Qur'an, tidak seorang pun berhak atas zakat tersebut kecuali mereka dan merupakan kewajiban pada setiap harta apabila telah mencapai nisab dan haul untuk dikeluarkan zakatnya.

Namun yang perlu diketahui, Abu Ubaid mengungkapkan ketentuan yang disepakati (tidak ada ikhtilaf), yaitu apabila sesorang memiliki harta yang wajib

\footnotetext{
${ }^{32}$ Euis Amalia, Sejarah Pemikiran Ekonomi Islam, (Depok: Gramata Publishing, 2010), h. 145.

${ }^{33}$ Ibid., h. 147-150.
} 


\section{Tahkím}

Vol. XIV, No. 1, Juni 2018

dizakati diantaranya 200 dirham, 20 dinar, 5 ekor unta, 30 ekor sapi, atau 40 ekor kambing. konsekuensinya, bila seseorang memiliki salah satu diatas dari awal haul sampai akhir, maka wajib mengeluarkan zakatnya yang dinamakan nishab oleh Imam Malik dan penduduk madinah sedangkan penduduk Iraq menyebutnya asal harta.

2) $\mathrm{Fa}^{\prime} \mathrm{i}$

Fa'i menurut bahasa adalah ar'rujuu berarti kembali, sedangkan menurut istilah fiqh adalah sesuatu yang diambil dari harta ahli kitab dengan cara damai tanpa peperangan atau setelah peperangan itu berakhir, disebut $f a^{\prime} i$ karena Allah mengembalikan harta tersebut kepada kaum muslimin.

Menurut versi Abu Ubaid adalah sesuatu yang diambil dari harta dzimmah perdamaian atas jizyah dari mereka, yang sebab itu jiwa mereka dilindungi dan dihormati. Harta fa'i digunakan untuk kepentingan pemerintah dan kesejahteraan umat. Bagian-bagian dari fa'i adalah;

\section{a) Kharaj}

Kharaj menurut bahasa ghullah yaitu penghasilan atau tanah taklukan kaum muslimin dengan jalan damai yang pemiliknya menawarkan untuk mengelola tanah itu sebagai pengganti sewa tanah dan bersedia memberikan sebagian dari hasil produksinya. Jumlah khurujnya setengah dari hasil produksi.

b) Jizyah ${ }^{34}$

Jizyah berasal dari kata jaza yang berarti imbalan atau kompensasi. Jizyah, adalah pajak tahunan yang wajib dibayarkan oleh non muslim khususnya ahli kitab untuk jaminan perlindungan jiwa, properti, ibadah, dan harta atau budak yang tinggal diwilayah pemerintah Islam. orang-orang non muslim disebut kafir zimmi atau orangorang yang dilindungi. Pajak ini juga disebut upeti atau poll-tax.

Pada masa Rasulullah saw, ketika memerintahkan kepada Muadz ibn Jabal atas ahli kitab di Yaman besarnya jizyah bagi masing-masing individu:

- 1 dinar atau

- 30 ekor sapi ( umur 1 tahun)

- 40 ekor sapi, jizyahnya 1 ekor musinah

- Penghasilan dari tanah 1/10 bila diairi dengan hujan dan 1/5 bila menggunakan biaya.

Jizyah dipungut berdasarkan ketetapan Al-qur'an, Qs. At-Taubah: 29 yang memerintahkan kaum mukminin: "perangilah orang-orang yang tidak beriman kepada Allah dan tidak (pula) kepada hari Kemudian, dan mereka tidak mengharamkan apa yang diharamkan oleh Allah dan RasulNya dan tidak beragama dengan agama yang

\footnotetext{
${ }^{34}$ Muhammad Sharif Chaudhry, Sistem Ekonomi Islam, (Jakarta: Kencana Prenada Media Group, 2012), h. 261
} 


\section{Tahkím}

Vol. XIV, No. 1, Juni 2018

benar (agama Allah), (Yaitu orang-orang) yang diberikan Al-Kitab kepada mereka, sampai mereka membayar jizyah dengan patuh sedang mereka dalam Keadaan tunduk.”

\section{c) Khumus}

Khumus menurut Abu Ubaid adalah 1/5 ghanimah dari ahli harbi, rikaz dan luqatah. Dalam pembahasan khumus Abu Ubaid menyebutkan bahwa harta yang terkena khumus yaitu sebagai berikut. ${ }^{35}$ Pertama beliau menafsirkan itu ghanimah sesuai firman Allah dalam Qs. Al-Anfal:41. Kedua, khumus yang diperoleh dari harta penambangan ataupun mineral dari harta yang terpendam/rikaz dan dipungut oleh negara Islam sebesar 20\%. Ketiga, khumus pada harta yang dipendam, sebagaimana terjadi ketika mujahid dari asy'sya'abi dimana seorang lelaki menemukan 1000 dinar yang dipendam diluar kota kemudian datang kepada Umar dan Umar mengambil 1/5 dari harta sebesar 200 dinar dan sisanya diberikan kepada orang yang menemukan. Kemudian 200 dinar itu dibagikan kepada kaum muslim. Keempat, khums juga ditarik atas apa yang diambil dari laut seperti mutiara, ambergris dan lainnya. Dilaporkan bahwa Khalifah Umar menarik khums dari mutiara dan menunjuk Yaali bin Ummayah sebagai pemungutnya.

Namun, perlu diketahui bahwa Abu Ubaid menyatakan bahwa ada tiga hukum yang dilakukan Umar pada harta benda yang dipendam. Pertama, harta itu diambil khumusnya dan sisanya diberikan kepada yang menemukan. Kedua, yang menemukan tidak diberikan harta itu, namun diserahkan sepenuhnya ke Baitul mal. Ketiga, harta itu diberikan sepenuhnya kepada yang menemukan dan tidak diserahkan ke Baitul mal.

d) $A l$ 'usyr

Al-'usyr merupakan jam' dari kata 'usyrun yaitu satu bagian dari sepuluh. Sedangkan menurut fuqaha terdapat dua pengertian, pertama 'usyr zakat yaitu sesuatu yang diambil dari zakat tanaman dan buah-buahan (Qs. Al-An'am:141). Kedua, 'usyr adalah sesuatu yang diambil dari harta kafir dzimmi yang melintas untuk perniagaan. Istilah usyr tidak dijumpai dalam Al-qur'an, tetapi dua ayat (Qs. Al-baqarah:276 dan Al-An'am:141) dipakai untuk merujuk padanya dan berdasarkan kedua ayat itulah usyr dipungut. $^{36}$

\section{Pembelanjaan Penerimaan Keuangan Publik}

Dalam masalah distribusi pendapatan memang erat kaitanya antara penerimaan dan pembelanjaan/pengalokasian untuk kepentingan publik. Abu Ubaid mengkhususkan sendiri mengenai persamaan manusia dalam kekayaan publik. Mengenai hal ini, diantaranya adalah komentar Abu Bakar ra, ketika datang padanya harta (fa'i/ghanimah), dia menjadikan (bagian) manusia sama, dan berkata "aku

\footnotetext{
${ }^{35}$ Ibid., h. 260-261.
}

${ }^{36}$ Ibid., h. 258. 


\section{Tahkim}

Vol. XIV, No. 1, Juni 2018

menginginkan terhindar dari meminta-minta dan memurnikan perjuangan (jihad)ku bersama Rasulullah saw, kelebihan mereka adalah disisi Allah, adapun dalam kehidupan ini persamaan adlah hal yang baik."

Dalam pendistribusian pengeluaran dari penerimaan khumus (khumus ghanimah, khumus barang tambang dan rikaz serta khumus lainnya) adalah ketentuan dari Rasulullah. Karena dana-dana publik merupakan kekayaan publik maka dialokasikan untuk kesejahteraan publik, seperti kesejahteraan anak-anak, korban bencana, santunan dan lainnya. ${ }^{37}$

\section{Hukum Pertanahan}

Pemikiran Abu Ubaid mengenai hubungan antar rakyat dan negara demi stabilitas kesejahteraan rakyat dan negara selain masalah administrasi keuangan publik yang terdapat dalam kitab al amwal, beliau berbicara mengenai hukum pertahanan.

Para fuqaha membagi tanah yang berada dalam wilayah negara islam menjadi tanah 'usyr dan kharaj. Dan Abu Uabid menyebutkan hukum pembagian tanah 'usyr yang bukan kharaj ada 4 macam: pertama, setiap tanah yang diserahkan oleh pemiliknya kepada negara, seperti tanah madinah, mekkah, thaif dan Yaman. Kedua, setiap tanah yang diambil kemudian negara tidak melihat menjadikannya fa'i, akan tetapi menjadikannya ghanimah yang dibagi empat dari 1/5 yang diambil diantara mereka yang turut menaklukan khususnya seperti yang telah dilakukan Rasulullah terhadap tanah khaibar. Ketiga, tanah biasa yang tidak diurusi dan dianggap, kemudian oleh kepala negara dipetakan kepada seseorang dijazirah arab atau daerah lainnya, seperti yang dilakukan Rasulullah dan Khulafaurrasyidin yang meng-iqtha tanah Yaman, Yamamah, Basrah. Keempat, setiap tanah yang mati dan dihidupkan oleh seorang muslim dengan mengairi dan menanaminya. Berikut ini adalah hukum-hukum pertahanan yang dikemukakan oleh Abu Ubaid: ${ }^{38}$

\section{a. Iqtha}

Iqtha ialah tanah yang diberikan oleh kepala negara kepada seorang rakyatnya untuk menguasai sebidang tanah dengan mengabaikan yang lainnya. Dalam kitab Alamwal, Abu Ubaid menafsirkan tanah bisa dijadikan iqtha dan yang tidak bisa. Dan biasanya setiap daerah atau tanah yang dihuni pada masa yang lama, kemudian ditinggalkan penghuninya maka keputusan hukum tanah itu diserahkan kepada kepala negara.

Kepala negara, begitu juga setiap tanah yang mati (tidak digarap) tidak ada seseorang yang mengelolanya dan tidak dimiliki oleh orang Islam atuapun orang kafir. Umar ra. Mengirim surat kepada Abu Musa “ jika tanah itu bukan tanah jizyah dan bukan tanah yang dialiri air jizyah, maka aku akan meng-iqtha tanah itu baginya."

\footnotetext{
${ }^{37}$ Euis Amalia, op.cit., , h. 150-151

${ }^{38}$ Ibid., h. 151-153
} 


\section{Tahkím}

Vol. XIV, No. 1, Juni 2018

Sedangkan kasus lain bahwa Rasulullah meng-iqthakan tanah kepada zubair yang ada pohon kurma dan pepohonan. Kami melihat tanah itu pernah Rasulullah mengiqthakan kepada kaum Anshar untuk mengelola dan mendiaminya. Kemudian tanah itu ditinggalkan, maka Rasulullah meng-iqthakan kepada Zubair.

Jadi, meng-iqtha hendaknya pemerintah menurut Abu Ubaid tidak meng-iqtha tanah kharaj, karena tanah kharaj adalah tanah yang produktif memberikan hasil dan dapat menambah devisa negara. Disisi lain, dengan memetakan tanah kharaj dapat memberi manfaat untuk para pengembala hewan ternak, dimana hal ini dapat menambah pertambahan produksi hewan yang sama pentingnya dengan masalah pertanian.

\section{b. Ihya al-Mawat}

Al Mawat adalah tanah yang mati, tandus tidak terurus, tidak ada pemiliknya dan tidak dimanfaatkan. Sedangkan maksud ihya al Mawat adalah membuka kembali lahan yang mati itu dengan membersihkannya, mengairi, mendirikan bangunan, dan menanamkan kembali benih-benih kehidupan pada lahan tersebut. Dalam hal ini negara berhak menguasai tanah yang mati dengan menjadikannya milik umum yang semua manfaatnya diserahkan kepada kemaslahatan umat.

Mengenai ihya al Mawat, Abu Ubaid membagi menjadi tiga bagian:

1. Seseorang datang ketanah tersebut lalu mengelola dan mendiaminya kemudian datang orang lain yang memperbaharui tanaman dan bangunan agar menjadi haknya tanah yang dikelola oleh orang sebelumnya. Dalam hal ini perbuatan orang tiu disebut al-irrqi al-Zhalim; perbuatan atas sesuatu yang bukan haknya dan ingin memiliknya. Adapun yang berhak atas tanah itu adalah orang yang pertama, seperti hadits riwayat Abu Hisyam, Rasulullah saw bersabda " siapa saja yang menghidupkan tanah mati maka tanah itu jadi miliknya dan tidak ada hak bagi irqi zalim."

2. Kepala negara meng-iqthakan kepada seseorang tanah mati, dan tanah itu menjadi milik penerima iqtha, kemudian orang itu menyia-nyiakan dengan tidak mengelola dan tidak mendiaminya, sehingga datang orang lain lalu mengelola dan mendiami serta menyangka tanah ini tidak ada yang mengurus. Dalam hal ini, pendapat Abu Ubaid merujuk pada yang dilakukan Umar ra, terhadap orang yang tidak memperoleh iqtha' pada masa Rasulullah. Kemudian ditelantarkan sampai pada masa Umar ra dan tanah itu digarap oleh orang lain, dengan berkata "kalau bukan iqtha' adri Rasulullah aku tidak akan memberimu sedikitpun."

3. Jika seseorang membangun tembok tanah apakah dengan iqtha' dari pemerintah atau tidak kemudian meninggalkanya pada waktu yang lama dengan tidak mendiaminya. Abu Ubaid berkata "pada sebagian hadits dari Umar, bahwa ia memberi batas tiga tahun dan melarang orang lain mendiami tempat tersebut." 


\section{Tahkím}

Vol. XIV, No. 1, Juni 2018

Selanjutnya, menurut Abu Ubaid bila tanah produk ihya' al mawat ini menghasilkan sesuatu dengan mengairi dan menanaminya, maka dikenakan zakat $1 / 10$ untuk 8 mustahiq zakat.

\section{c. Hima}

Dalam hal ini yang dinamakan hima adalah perlindungan, menurut Abu Ubaid adalah tempat dari tanah yang tidak berpenduduk yang dilindungi oleh kepala negara untuk tempat mengmbala hewan-hewan ternak. Tanah hima ini adalah tanah yang mendapat perlindungan dari pemerintah, namun dapat dimanfaatkan oleh seluruh umat, seperti air, rumput, tanaman, hal ini sesuai dengann sabda Rasulullah saw, "orang muslim adalah saudara bagi muslim yang lainnya, yang memberi mereka keleluasaan air dan rumput".

\section{Fungsi Uang}

Menurut Abu Ubaid terdapat dua fungsi uang yang tidak mempunyai nilai intrinsik sebagai standar dari nilai pertukaran dan sebagai media pertukaran. Dalam hal ini ia menyatakan "adalah hal yang tidak diragukan lagi bahwa emas dan perak tidak layak untuk apapun kecuali keduanya menjadi harga dari barang dan jasa. Keuntungan yang paling tinggi yang dapat diperoleh dari kedua barang ini adalah penggunaanya untuk membeli sesuatu."

Pernyataan Abu Ubaid tersebut menunjukan bahwa ia mendukung teori konvesional mengenai uang logam. Walaupun sama sekali tidak menjelaskan mengapa emas dan perak tidak layak untuk apapun kecuali keduanya menjadi harga dari barang dan jasa. Tampaknya, Abu Ubaid merujuk pada kegunaan umum dan relatif konstannya nilai dari kedua benda tersebut dibandingkan dengan komoditas lainnya. Disamping itu, Abu Ubaid secara implisit mengakui adanya fungsi uang sebagai penyimpanan nilai ketika membahas jumlah tabungan minimum tahunan yang wajib terkena zakat. ${ }^{39}$

Salah satu ciri khas kitab al-Amwal di antara kitab-kitab lain yang membahas tentang keuangan publik (public finance) adalah pembahasan tentang timbangan dan ukuran, yang biasa digunakan dalam menghitung beberapa kewajiban agama yang berkaitan dengan harta atau benda dalam bab khusus. Dalam bab ini Abu Ubaid juga menceritakan tentang khilafah Abdul Al-Malik Ibn Al-Marwan dalam melakukan standarisasi dari berbagai jenis mata uang yang ada dalam sirkulasi. ${ }^{40}$

\section{Karya-Karya Abu Ubaid}

Hasil karyannya ada sekitar 20, baik dalam bidang ilmu Nahwu, Qira'ah, Fiqih, Syair dan lain-lain. Yang terbesar dan terkenal adalah Kitab Al-Amwal dalam bidang Fiqih. Kitab Al-Amwal dari Abu Ubaid merupakan suatu karya yang lengkap tentang keuangan negara dalam Islam.

\footnotetext{
${ }^{39}$ Ibid., h. 155

${ }^{40}$ Adiwarman Azwar Karim, op.cit., h. 270-280
} 


\section{Tahkím}

Vol. XIV, No. 1, Juni 2018

Buku ini sangat kaya dengan sejarah perekonomian dari paruh pertama Abad ke $2 \mathrm{H}$. Buku ini juga merupakan rangkuman (compendium) tradisi asli dari Nabi dan Atsar para sahabat dan tabi' in tentang masalah ekonomi. Sedikitnya ada 4 jenis produk hukum Islam yang ada selama ini, yaitu kitab-kitab Fiqih, keputusan-keputusan pengadilan agama, peraturan perundangan di negeri-negeri muslim, dan fatwa-fatwa.

Kitab al-Amwal merupakan sebuah mahakarya tentang ekonomi yang dibuat oleh Abu Ubaid yang menekankan beberapa issu mengenai perpajakan, hukum, serta hukum administrasi dan hukum internasional. Kitab Al-Amwal secara komprehensif membahas tentang sistem keuangan publik Islam terutama pada bidang administrasi pemerintahan. Kitab ini juga memuat sejarah ekonomi Islam selama dua abad pertama hijriyah, dan merupakan sebuah ringkasan tradisi Islam asli dari Nabi, para sahabat dan para pengikutnya mengenai permasalahan ekonomi. Abu ubaid, dalam Kitab AlAmwal, banyak mengutip pandangan dan perlakuan ekonomi dari imam dan ulama terdahulu. Ia sering mengutip pandangan Malik ibn Anas dan pandangan sebagian besar ulama madzhab Syafi'i lainnya, dan juga mengutip beberapa ijtihad Abu Hanifah, Abu Yusuf dan Muhammad ibn al-Hasan asy-Syaibani. ${ }^{41}$

\section{Pemikiran Ekonomi Tokoh Menurut Pendapat Lain}

Dari literatur-literatur yang ada tidak begitu ditemukan pandangan mengenai pemikiran-pemikiran dari Al Syaibani ini. Penulis dapatkan sebuah pandangan dari Janidal, seorang ekonom Islam bahwa Al-Syaibani merupakan seorang perintis ilmu ekonomi dalam Islam. Ia mendasari pernyataan tersebut berdasarkan Karya Al-Kasb yang ditulis oleh Al-Syaibani. Bahasan Al-Kasb yang berkaitan dengan perilaku produksi, kerja, kekayaan dan kefakiran, klasifikasi usaha perekonomian, kebutuhan ekonomi, dan spesialisasi kerja merupakan kitab pertama dalam dunia Islam yang membahas masalah tersebut. ${ }^{42}$

Dalam ekonomi konvensional dikenal juga pencetus spesialisasi kerja yakni Adam Smith. Dalam bukunya Wealth of Nation iya menyatakan bahwa "Pekerjaan yang dilakukan suatu bangsa adalah modal yang membiayai keperluan hidup rakyat itu pada asal mulanya, dan dengan hasil-hasil pekerjaan tersebut dapat dibeli keperluankeperluan hidupnya di luar negeri.“ Kapasitas Produktif daripada kerja selalu bertambah dikarenakan adanya pembagian kerja yang mendasar dan rapi.

Keuntungan adanya pembagian kerja tersebut dianalogikan dengan contoh sebuah pabrik jarum. Di dalam pabrik jarum tersebut seorang buruh secara pasti dapat membuat 20 jarum sehari. Dari hasil kunjungan Smith atas suatu pabrik jarum yang telah dilakukan pembagian pekerjaan, ternyata 10 orang buruh dapat membuat 4.800 buah jarum, dengan pembagian kerja yaitu ada yang khusus meruncingkan jarumnya,

${ }^{41}$ http://ekonomi-islam.com/pemikiran-abu-ubaid-dalam-ekonomi (dikutip pada tanggal 2

${ }^{42}$ Adiwarman A. Karim, op.cit., h. 256-257 


\section{Tahkím}

Vol. XIV, No. 1, Juni 2018

serta lainnya. Dari keadaan tersebut dapat dikemukakan bahwa pembagian pekerjaan yang dilaksanakan itu dapat mempertinggi hasil produksi buruh menjadi 4.800 buah jarum atau meningkatkan sebanyak 240 kali lipat.

Pembagian pekerjaan sering dibedakan menjadi dua pengertian. Pertama adalah membagi pekerjaan menjadi sederhana sehingga semua buruh pada tingkat tertentu dapat melakukan pekerjaan. Kedua adalah pembagian kerja yang bersusun yang membagi pekerjaan sesuai dengan keahlian khusus yang berdampak kepada pekerjaan yang lebih tersistem dan membutuhkan spesialisasi khusus. Dengan adanya sistem tersebut, maka akan tercapai maksimalisasi dalam hal produksi suatu lembaga.

Secara garis besar pada dasarnya antara sistem spesialisasi pekerjaan yang dicetuskan oleh Al-Syaibani dan Adam Smith punya kesamaan yang sangat mendasar yakni bahwa dengan adanya pekerjaan yang dilakukan berdasarkan keakhlian maka akan berdampak pada semakin baiknya hasil dari suatu usaha. Hal ini bisa tergambar jelas dari penelitian sederhana yang telah dilakukan oleh Adam Smith di atas bahwa dengan adanya spesialisasi pekerjaan tersebut akan berdampak pada peningkatan kuantitas dan kualitas sebuah pekerjaan. Selain itu dengan adanya spesialisasi pekerjaan tersebut maka setiap individu yang ada dalam suatu pekerjaan dapat mengerjakan sesuatu sesuai dengan aturan tanpa harus mengerjakan apa yang tidak seharusnya ia lakukan. Sumbangsih pemikiran Al Syaibani dan Adam Smith mengenai spesialisasi pekerjaan ini telah memberikan efek yang sangat besar hingga saat sekarang terutama bagi dunia usaha.

Sedangkan jika menilik pada perbedaannya dalam pandangan penulis adalah bahwa dalam spesialisai yang dikemukan oleh Al Syaibani terdapat penekanan pada unsur kerja sama dan prinsip saling membutuhkan antara satu dan lainnya dalam melaksanakan suatu pekerjaan. Disini terdapat makna besar bahwa apapun posisi yang ditempati seorang pekerja ia mempunyai fungsi sesuai dengan posisinya tersebut. Dimana tanpa menjalankan hal tersebut maka hasil dari pekerjaan yang ada tidak akan tercapai secara maksimal. Ini sangat menunjukkan betapa sistem spesialisasi yang dicetuskan Al-Syaibani sangat menjunjung tinggi nilai kemanusiaan tanpa memandang rendah dan tingginya jabatan dalam pekerjaan. Sementara dalam spesialiasi yang dicetuskan adam Smith dalam Wealth of Nation, tidak tergambar akan bagaimana rasa manusiawi ini. Dalam teori tersebut hanya bertumpu pada maksimalisasi hasil dari sebuah pekerjaan yang ada.

Yang paling mendasar, bahwa suatu pekerjaan yang dilakuakn setiap orang adalah orientasi dalam rangka mencapai ridha Allah yang merupakan wujud dari ibadah kepadaNya. Bagi Al Syaibani ini adalah fondasi utama dari setiap pekerja yang ada dalam usaha produksi Islam. Segala bentuk posisi dan tanggung jawab yang ada dalam pekerjaan merupakan manifestasi dari upaya peribadatan kepada Allah disamaping upaya pemenuhan kebutuhan hidup. Dimana dikenal dengan penguasaan dua aspek 


\section{Tahkím}

Vol. XIV, No. 1, Juni 2018

sekaligus yakni ekonomi dan religius. Sementara Adam Smith, sangat jauh dari unsur keagamaan dalam mencetuskan teorinya. Pemikiran Adam Smith hanya bertumpu pada satu aspek yakni aspek ekonomi, dimana adanya spesialiasi pekerjaan hanya bertujuan untuk meningkatkan produksi yang berefek pada semakin baiknya perekonomian.

Di sini bisa dijadikan suatu bahan perenungan bahwa ternyata Islamlah yang pertama kali mencetuskan sistem spesialisasi kerja ini melalui Al Syaibani bukan Adam Smith seperti yang sering didengung-dengungkan oleh ekonom barat. Kita harus berbangga dan sekaligus miris akan kenyataan tersebut. Akan tetapi, kita dapat memberikan sumbangsih nyata berkaitan dengan hal ini. Dimana kita dapat membuat tulisan-tulisan maupun komentar-komentar berkaitan dengan masalah spesialisasi kerja yang kita ambil dari sumber-sumber pemikiran Al-Syaibani sehingga kedepan semakin banyak orang terutama umat Islam yang mengenal Al-Syaibani dan tahu bahwa beliaulah pencetus spesialisasai kerja pertama dalam Islam.

\section{Relevansinya pemikiran Abu Ubaid di Indonesia}

Pada dasarnya pemikiran Abu Ubaid tentang zakat adalah penerapan dan pengelolaan zakat yang diprakteknya pada masa Rasulullah saw dan para sahabatnya. Prinsip dari pengelolaan zakat pada masa tersebut adalah adanya peran pemerintah sebagai pemegang kekuasaan politik dalam pengelolaan zakat, pembentukan institusi zakat sebagai institusi keuangan publik, dan pola distribusi zakat.

Secara prinsip pengelolaan zakat pada masa tersebut dapat diaplikasikan pada masa kini, khususnya pengelolaan zakat di Indonesia. Beberapa kebijakan pemerintah mengenai pengelolaan zakat merupakan peran pemerintah dalam hal menjamin pengelolaan zakat di tanah air. Akan tetapi diperlukan beberapa perbaikan dan penyelarasan, serta pengawasan dalam praktek zakat di lapangan. Dengan memperhatikan beberapa hal di atas, diharapkan pola dan system pengelolaan zakat di Indonesia lebih baik dan dapat memberikan kontribusi dalam pembangunan ekonomi nasional, khususnya tingkat perekonomian umat muslim yang merupakan mayoritas penduduk di Indonesia.

Indonesia merupakan negara berpenduduk muslim terbesar di dunia. Hal tersebut merupakan potensi sekaligus masalah buat kita. Dengan jumlah yang cukup besar, umat muslim di Indonesia dapat memberikan kontribusi yang sangat besar dalam pembayaran zakat. Namun, dengan posisi Indonesia sebagai negara berkembang, tentunya sebagai mayoritas, umat muslim Indonesia tidak pernah luput dari permasalahan-permasalahan yang pada umumnya dialami oleh negara berkembang, yaitu masalah kemiskinan.

Sebagai negara demokrasi, pemerintah telah dengan serius memperhatikan kebutuhan-kebutuhan umat muslim Indonesia dan memfasilitasi beberapa kebijakan dalam rangka memberikan kemudahan atas pelaksanaan ajaran agama Islam. Di antara kebijakan tersebut adalah kebijakan tentang zakat yang diwujudkan dalam bentuk 


\section{Tahkím}

Vol. XIV, No. 1, Juni 2018

undang-undang. Salah satu kebijakan pemerintah tersebut adalah Undang-Undang No. 38 Th. 1999 tentang pengelolaan zakat dan Keputusan Menteri Agama RI No. 581 Th. 1999 tentang pelaksanaan UU No. 38 Th. 1999 tersebut. Undang-undang tersebut dirancang sebagai upaya perbaikan pengelolaan zakat di Indonesia.

Dengan adanya beberapa kebijakan pemerintah dalam hal pengelolaan zakat, tugas dan tanggung jawab pemerintah tidak otomatis hilang. Pemerintah diharapkan dengan aktif mengontrol dan memberikan peringatan bagi lembaga-lembaga zakat yang tidak mengelola zakat dengan baik. Meskipun undang-undang telah dibuat, permasalahan tentang pengelolaan zakat, khususnya lembaga-lembaga pengelola zakat masih akan timbul, seperti persaingan antara Lembaga Amil Zakat (LAZ) yang berbasis lembaga swadaya masyarakat dan lembaga yang dibentuk pemerintah Badan Amil Zakat (BAZ).

Abu Ubaid bin Salam bin Miskin bin Zaid al-Azdi adalah salah satu yang telah menyoroti praktik perdagangan internasional, khususnya impor dan ekspor. Perdagangan Internasional adalah perdagangan antarnegara yang melintasi batas-batas suatu negara. Jauh sebelum teori perdagangan internasional ditemukan di Barat. Islam telah menerapkan konsep-konsep perdagangan internasional. Jika kita amati dari penjelasan di atas, ada hal yang menarik di sana. Cukai merupakan salah satu bentuk merugikan orang lain, yang sekarang ini didengungkan oleh penganut perdagangan bebas (free trade), bahwa tidak boleh ada tarif barrier pada suatu negara. Barang dagangan harus bebas masuk dan keluar dari suatu negara. Dengan kata lain, bea masuknya nol persen. Tetapi dalam konsep Islam, tidak ada sama sekali yang bebas, meskipun barang impor itu adalah barang kaum muslimin. Untuk barang impor kaum muslimin dikenakan zakat yang besarnya $2.5 \%$. Sedangkan non muslim, dikenakan cukai 5\% untuk ahli dzimmah (kafir yang sudah melakukan perdamaian dengan Islam) dan $10 \%$ untuk kafir harbi (Yahudi dan nasrani). Jadi, tidak ada prakteknya sejak dari dahulu, bahwa barang suatu negara bebas masuk ke negara lain begitu saja.

\section{Kesimpulan}

Pemikiran Al Syaibani lebih menekankan kepada permasalahan ekonomi mikro, sehingga pemikirannya membahas secara detail bagaimana peranan ekonomi dari cara kerja manusia untuk mendapatkan harta, sedangkan Abu Ubaid menekankan kepada permasalahan ekonomi makro, bagaimana suatu negara mengatur tatanan ekonomi demi kesejahteraan rakyatnya.

Menurut Al-Syaibani, permasalahan ekonomi wajib diketahui oleh umat islam karena dapat menunjang ibadah wajib. Pemikiran beliau tentang ekonomi terbagi menjadi lima bagian, yaitu: al-Kasb (kerja), kekayaan dan kefakiran klasifikasi usahausaha perekonomian, kebutuhan-kebutuhan ekonomi, spesialisasi dan distribusi pekerjaan. Sektor usaha yang harus lebih diutamakan menurut Asy-syaibani adalah sektor pertanian, karena pertanian merupakan sektor usaha yang memproduksi 


\section{Tahkím}

Vol. XIV, No. 1, Juni 2018

berbagai kebutuhan dasar manusia yang sangat menunjang dalam melaksanakan berbagai kewajibannya.

Pemikiran Abu Ubaid yang tertuang dalam kitab al amwal yang membahas secara mendalam tentang hak dan kewajiban negara, pengumpulan dan penyaluran zakat, khums, kharaj, fai dan berbagai sumber penerimaan negara lainnya, dimana analisis yang digunakan beliau merujuk pada kaidah hadits-hadits yang berkaitan dengan pemerintahan.

\section{DAFTAR PUSTAKA}

A.Karim, Adiwarman. Sejarah Pemikiran Ekonomi Islam, Ed. 3; Jakarta: PT. Raja Grafindo Persada, 2004

Amalia, Euis. Sejarah Pemikiran Ekonomi Islam Dari Masa Klasik Hingga Kontenporer, Jakarta : Gramata Publishing, 2010

Al-Audi, Rifa'at. Min al-Turats: al-Iqtishad li al-Muslimin, Cet. 4; Makkah: Rabithah 'Alam al Islami, 1985

Chaudhry, Muhammad Sharif. Sistem Ekonomi Islam, Jakarta: Kencana Prenada Media Group, 2012.

Dahlan, Abdul Aziz, dkk (ed.). Ensiklopedi Hukum Islam, Jilid 5, Cet. 1; Jakarta : PT. Ichtiar Baru Van Hoeve, 1997

http://ekonomi-islam.com/pemikiran-abu-ubaid-dalam-ekonomi

Al-Janidal, Hammad bin Abdurrahman. Manahij al-Bahitsin fi al Islami, Riyadh: Syirkah al Ubaikan li al Thaba' ah wa al Nasyr, Jilid 2, $1046 \mathrm{H}$

Jaya Bakri, Asafri, Konsep Maqashid Syari'ah menurut Al Syatibi, Jakarta: PT. Raja Grafindo Persada, Cet. ke-1, 1996.

M. Sadeq, Abulhasan dan Aidit Ghazali, Reading in Islamic Economic Thought, Cet. 1; Selangor Darul Ehsan: Longman Malaysia, 1992.

Al-Nabhani, Taqiyuddin. Membangun Sistem Ekonomi Alternatif: Perspektif Islam, Cet. 2; Surabaya: Risalah Gusti, 1996

Al-Syaibani, Muhammad bin Hasan Al Hasan. al Iktisab fi al Rizq al Mustahab, Cet. 1; Beirut: Dar al Kutub al Ilmiyyah, 1986 